\title{
Zeszyty PRASOZNAWGZE
}

Kraków 2019, t. 62, nr 2 (238), s. 271-275

DOI: $10.4467 / 22996362 \mathrm{PZ} .19 .030 .10555$

www.ejournals.eu/Zeszyty-Prasoznawcze/

\section{WSPOMNIENIE O WALERYM PISARKU}

\author{
Michał M. Bukowski \\ (iD) orcid.org/0000-0002-7336-453X \\ Instytut Dziennikarstwa, Mediów i Komunikacji Społecznej \\ Uniwersytet Jagielloński
}

- Portki piorę sam, i sam też zmywam po sobie - grzecznie, lecz zdecydowanie rzucił Walery Pisarek, gdy usiłowałem podnieść jego filiżankę po kawie. Wspólna kawa była zwieńczeniem drobnego sukcesu. Służbowy komputer Profesora nie działał od wielu tygodni. Obsługa poczty elektronicznej ograniczała się tylko do jej odbioru, nie dało się wysłać czegokolwiek. Profesor czytał w pracy, a odpisywał z domu. MS Windows 98 i firmowy Outlook, wybuchowa mieszanka frustracji. Rozwiązanie okazało się szybkie i proste, ale głęboko ukryte w gąszczu programowych ustawień i informatycznej nowomowy. Kiedyś spędziłem już nad tym kilka bitych godzin, więc teraz poszło mi łatwo. Pisarek był wniebowzięty. Zarządził świętowanie przy kawie i ciastku z ośrodkowych zapasów. I tak pewnego wiosennego, słonecznego popołudnia, w dobrych humorach, piliśmy kawę na pierwszym piętrze Ośrodka Badań Prasoznawczych przy ulicy Świętego Filipa w Krakowie.

Do Ośrodka Badań Prasoznawczych po raz pierwszy zawitałem w październiku 1998 roku. Szarobura aura tego dnia zapowiadała szaroburą jesień, co świetnie komponowało się z szaroburym Krakowem tamtego czasu. Rozpocząłem studia dziennikarskie na Uniwersytecie Jagiellońskim i od razu, choć na krótko, stałem się sławny na roku. Jakiś srogi wykładowca bezwzględnie kazał przeczytać coś na kolejne zajęcia i rzucił, że właściwa książka znajduje się w bibliotece OBP. Dmuchając na zimne, poszedłem tam od razu po wykładzie. Pożyczało się wówczas pod zastaw legitymacji studenckiej, na piękne oczy lub na wpis do kajecika. U mnie padło na legitymację, którą później pracownicy biblioteki OBP pokazywali wszystkim 
moim nowym kolegom i koleżankom - wściekłym, że jedyny egzemplarz jest już niedostępny. Ale potem historia potoczyła się pomyślnie. Byłem częstym gościem w OBP, a szczególnie bibliotece. Jej pracownicy mnie rozpoznawali. Andrzej Zagrodnik, Janina Maczuga, Barbara Breitmeier stanowili dla mnie jakby jedną osobę magicznego bibliotekarza, takiego wprost od Borgesa. Przychodziłem porozmawiać, popytać, raczej posiedzieć, aniżeli naprawdę postudiować. Patrząc z perspektywy czasu, mógłbym powiedzieć, że prowadziłem obserwację etnograficzną tego, jako nowoczesność radośnie wykańcza staroczesność. Ale wówczas tego tak nie nazywałem.

- Uniwersytet Jagielloński od 641 lat jest, proszę Pani, w Krakowie! Żegnam! - uniósł się Walery Pisarek i elegancko trzasnął słuchawką. Jakiś leming płci żeńskiej leciał bezmyślnie po numerach telefonów, usiłując wcisnąć komukolwiek to, co mu wciskać kazali. Pisarek, najwyraźniej nieprzyzwyczajony jeszcze do takich aspektów gospodarczej wolności, ufnie podjął rozmowę i dał się złapać. Chwilę to trwało. Dopiero pytanie o siedzibę miejscową „firmy” uzmysłowiło mu, że dyskutuje z żywym automatem. Poza tym przypadkiem chyba nigdy nie widziałem Profesora wzburzonego. Był Pisarek człowiekiem umiaru, wyznawcą zasady złotego środka, tak w postawie dydaktyczno-badawczej, jak i - na tyle, na ile mogłem to wyczuć - polityczno-społecznej. Moje prace magisterska oraz doktorska, pisane pod jego kierunkiem, miały w sobie wiele argumentów radykalnych i momentami przesadzonych. Pisarek zawsze je wyłapywał, ale nigdy z miejsca nie odrzucał - sugerował, by je perswazyjnie lepiej uzasadnił, jeśli się przy nich upieram. Jako promotor dawał bardzo dużo swobody, ale wymagał spójności wewnętrznej tekstu. Lubił jasno wyrażoną ideę, pomysł, który jest na tyle ciekawy, że sam dźwiga cały tekst. Dowód zawsze będzie atakowany i podgryzany z różnych stron, ale autentycznie dobry pomysł znajdzie uznanie w oczach nawet najbardziej zaciekłych krytyków. Wyzwanie na całe zawodowe życie.

\section{$* x *$}

- Naprawdę? Zrobi Pan to? Niemożliwe - zachwycał się Walery Pisarek, gdy z mozołem wwiercałem kochanego Piłsudskiego do ściany, uważając, by nie spadł i się nie potłukł. Gdyby zleciał, to nie wiem, jakbym spojrzał w oczy Profesora. Piłsudskiego przywiózł osobiście do nowej siedziby OBP na III Kampusie UJ. Marszałek wisiał na św. Filipa, wisiał na Radziwiłłowskiej, zapewne wisiał na Wiślnej i na Rynku. Zawiśnie także na Łojasiewicza. Wiertarka $\mathrm{z}$ udarem nie dawała sobie rady. Wbiłem się w cienką warstwę tynku, lecz wiertło, choć takie specjalne do betonu, zaczęło się ślizgać. Za mało, za płytko. Dopiero po trzydziestu minutach wiercenia wcisnąłem kołek, powiesiłem Marszałka i kontrolnie szarpnąłem go kilka razy w dół. 
Wiedziałem, jak wiele znaczy dla Profesora. W Pisarkowym uwielbieniu dla idei zgodnego, wolnego, wiecznego narodu tkwiło coś rozkosznie naiwnego i pięknego zarazem. Patrzyłem na to $\mathrm{z}$ boku, bacząc na słowa w rozmowach, by Profesora nie urazić. Ale patrzyłem krytycznie, gdyż wydawało mi się, że przecież na naszych oczach cała ta idea harmonijnej wspólnoty wyobrażonej idzie do piachu, a naród lada dzień dosłownie, nie metaforycznie, skoczy sobie do gardeł. Może Profesor widział i przeżył tak wiele, że miał lepszy ogląd rzeczywistości i nie ulegał złudzeniom? A może żył ideą, w którą wierzył bez względu na wszystko, bo była dla niego piękna i dobra? Po latach rozumiem to tak, że naukowiec musi racjonalnie rozważać wszystkie racje i nieustannie modyfikować swoje poglądy w zależności od ustaleń nauki, ale to emocje czynią nas ludźmi. Marszałek nigdy nie spadł, ale wielkie fale uniwersyteckich reorganizacji zdjęły go ze ściany i przededniu stulecia odzyskania niepodległości postawiły w kącie.

- Hejże! Hola! A gdzie są moje klucze? - zapytał szczerze zdziwiony Pisarek, gdy podczas ośrodkowego sylwestra poszedłem zanieść płaszcze gości do jego gabinetu i wróciłem z pustymi rękami. Po drodze któryś z wieloletnich pracowników Ośrodka polecił mi, bym już nie zamykał i zostawił klucze w drzwiach, bo i tak wszyscy są na miejscu, a zaraz przyjdą kolejni goście i znów trzeba będzie otwierać. Ale Profesor lubił porządek (choć w szufladach biurka zawsze miał twórczy bałagan), więc zerwał się i sam pobiegł załatwić sprawę. Będą kolejni goście, to znów się otworzy. A tak, to lepiej nie kusić losu. Było zamknięte, ma pozostać zamknięte.

W mojej pamięci Walery Pisarek jako postać zlewa się z czasem, miejscem i innymi osobami Ośrodka. Budynek przy św. Filipa wciąż wydaje mi się odwieczną twierdzą OBP. To paradoks. Wiem, że gdy dotarłem tam po raz pierwszy, oni dopiero co się sprowadzili. Wiślnej nie znałem. Na św. Filipa razem byliśmy nowi. Nowe i jednocześnie stare były ośrodkowe pożegnania mijającego roku i okolicznościowe imprezy. Przychodziło wówczas naprawdę sporo ważnych osób. Profesor jednak zawsze pozostawał jakby w tle. Formalnie wówczas już nie pełnił funkcji gospodarza Ośrodka, ale oczywiście był tam najważniejszą figurą. W większym gronie nigdy jakoś nie wysuwał się do przodu, choć nie można powiedzieć, by cechowała go nieśmiałość. Miał tę umiejętność niedominowania nawet wówczas, gdy niejako naturalnie ta dominacja mogła się pojawiać.

- Nigdy w historii Ośrodek nie miał takich warunków, jak tutaj - szeroko uśmiechnął się Profesor, widząc pomieszczenia oddane OBP w III Kampusie UJ. Powiedział to $\mathrm{w}$ taki sposób, że nie umiałem wyczuć, czy kulturalnie przemawia przez niego subtelny kpiarz, czy też dobroduszny, nieco naiwny starszy pan. $Z$ ulicy św. Filipa 
Ośrodek przeniósł się na ul. Radziwiłłowską, gdzie Pisarka upchnięto na strychu. Wszyscy siedzieli na walizkach, bo i tak było wiadomo, że wkrótce się przenoszą na III Kampus.

Budynek należący do III Kampusu, owszem, był nowoczesny: windy, projektory, zamki elektroniczne, marmur na podłodze i inne bajery, ale brakowało w tym miejscu magii. A chyba tylko ona mogła podtrzymać tę historię. Ośrodek stał się trzema pokojami dosłownie wtopionymi w wielki wydział szkolenia zawodowego w zawodach bliżej nieokreślonych, ale o nazwach wielce chwytliwych. Profesor wtedy już emeryt - przyjeżdżał raz w tygodniu z drugiego końca Krakowa. Ale czuł się obco i trudno było tego nie widzieć, choć trzymał fason i starał się maskować. W labiryncie korytarzy, po których bez przerwy w tę i we w tę plątają się ludzkie cienie z komórkami przy uchu, trudno było poczuć się jak w instytucji naukowej. Profesor znalazł się w „firmie”, w której każdy jest tabelką w Excelu, a algorytm wskazuje, kogo do kogo dodać lub od kogo odjąć, by było tak, jak ma być.

\section{$* * *$}

- Skąd Pan to wie? Skąd Pan to wie? A to? - pisał do mnie Profesor kolorem czerwonym na marginesach stron pierwszego rozdziału mojej pracy magisterskiej. Studiowałem w trybie pięcioletnim, nie było licencjatów. To była pierwsza poważna praca naukowa. Eseje zaliczeniowe i prace projektowe rządziły się swoimi prawami. Pisaliśmy to, co nam się z grubsza wydawało prawdą. Teraz musiałem zmierzyć się $\mathrm{z}$ wnioskowaniem i dowodzeniem.

- Skąd Pan to wie?

- No... nie wiem dokładnie skąd.

Trzeba wiedzieć dokładnie. W seminarium uczestniczyło dziesięć osób. Wszyscy mieliśmy ten sam problem. Walery Pisarek wysoko ustawił poprzeczkę. Ale znowu bez przesady! Jasno przedstawiony problem badawczy, czytelne hipotezy, uzasadnione definicje, poprawne operacjonalizacje. To na początek. Niektórzy od razu się wypisali. Nikt jakoś szczególnie nie chciał trafić akurat do Pisarka. Znaliśmy go wcześniej tylko z zajęć z retoryki, a te wydawały się zbyt językoznawcze jak na nasze możliwości. Tym większe było zaskoczenie, gdy od razu okazało się, że Profesor jest $\mathrm{w}$ stanie $\mathrm{z}$ miejsca twórczo i sprawnie przeformułować każdy zaproponowany przez nas temat tak, by mógł go z czystym sumieniem promować, a jednocześnie byśmy pisali to, o czym chcemy pisać. Wilk syty i owca cała. Pisarek często powtarzał po Einsteinie: Jeśli nie potrafisz jasno wyrazić swojej myśli, to znaczy, że sam jej nie rozumiesz. Sam zawsze pisał jasno, zrozumiale, ciekawie i z humorem. Jakież było moje zdziwienie, gdy - już jako pracownik dydaktyczny - dowiedziałem się od studentów, że „Analiza zawartości prasy” uchodzi za książkę trudną i niezrozumiałą. Jak to? Prościej się już przecież nie da!

Pierwszy raz w życiu widziałem Walerego Pisarka kilka lat wcześniej. Trwał drugi rok studiów. Staliśmy upakowani w ciasnym korytarzu OBP. Jakieś zaliczenie, wpisy do indeksów, długie popołudnie spędzone w kolejce. Obok nas przemknęła 
szybkim krokiem postać w długim prochowcu. Wysoki (taki się wydawał!), lekko pochylony mężczyzna z długą, siwą brodą. Był jakiś kontrast między tą brodą a energetycznym, zdecydowanym krokiem. Dopadł do końca korytarza i zniknął w drzwiach po prawej.

- Widzieliście? Walery Pisarek - rzucił ktoś ze znajomych.

- Ten Pisarek? Ten słynny? Ten od książek?

Wielu $\mathrm{z}$ nas znało go z dzieciństwa jako popularnego autora, ale nie mieliśmy pojęcia, że tu pracuje i że będziemy mieli z nim zajęcia.

Wiosennego popołudnia pierwszej dekady nowego stulecia, w dobrym humorze po pomyślnej naprawie komputera, piłem kawę z Walerym Pisarkiem na pierwszym piętrze Ośrodka Badań Prasoznawczych przy ulicy Świętego Filipa. Kawę zaparzył Profesor. Gabinet rozświetlało ostre światło słoneczne. Było ciepło i spokojnie. Na długim stole leżały nieuprzątnięte jeszcze sterty papierów: rozdziały prac magisterskich, jakieś pokreślone ołówkiem fragmenty maszynopisu, Der Spiegel i pocztówka od przyjaciela Ośrodka z drugiego końca świata. Piłem kawę i obserwowałem bieg sekundnika na firmowym zegarze tygodnika Polityka. Pamiątka po lepszych czasach. Nie dobiegał nas żaden dźwięk. W Ośrodku nie pozostał już nikt. Ci zbędni zostali zwolnieni, nieużywane pomieszczenia zaryglowane, szpargały rozdane lub odstawione do wyrzucenia. Lada dzień miała się zjawić specjalnie zamówiona ekipa, fachowcy od utylizowania przeszłości. Wszystko było gotowe na zakończenie. W opustoszałym budynku siedzieliśmy w milczeniu. 